\title{
Captive Hill Mynah Gracula religiosa breeding success: potential for bird conservation in Thailand?
}

\author{
MANEE ARCHAWARANON
}

\section{Summary}

Hill Mynah Gracula religiosa is one of the most popular bird pets worldwide due to its ability to mimic diverse sounds, especially human speech. However, Mynahs have rarely been bred in captivity, so nestlings from natural populations are in large demand, resulting in many populations being threatened with extinction. Both subspecies in Thailand, intermedia and religiosa, are costly and desired in the pet market. Captive breeding is one of the most practical strategies to solve a conservation problem of this nature and this report describes a success in breeding Hill Mynahs in captivity. Mated pairs were given free access to food, nest-cavities and nest materials. Reproductive behaviour in captivity was not different from that in the wild, with the exception that breeding occurred throughout the year, even during the non-breeding season for wild populations. Although there are doubts concerning the reintroduction of captive-bred birds and whether successful Hill Mynah breeding in captivity is an economically competitive alternative to poaching, it ensures species survival in captivity as the risk of extinction increases.

\section{Introduction}

Pet trade is a major reason why wild birds are taken from the forest areas of Asia, Africa and Latin America. Furthermore, in order to access birds, the poachers cut down trees or destroy nest-cavities, resulting in permanent habitat destruction. The case of the Hill Mynah Gracula religiosa is an example of how the pet trade directly affects a wild population (Bertram 1969, Archawaranon 2003). The birds' ability to mimic many sounds, and especially human speech, has created a great demand for them as pets.

In a report on the plight of Thailand's birdlife, Martin (1973) used information from the Thai Government to show that from 1967 to 1971 , as many as 200,334 Hill Mynahs were legally exported at the rate of 28,111 to 61,964 per year. More Hill Mynahs were exported than Parakeets Psittacula spp. (139,783), Munias Lonchura spp. (108,619), Chestnut Munia Lonchura malacca $(96,244)$ or Scarlet-backed Flowerpecker Dicaeum cruentatum $(34,674)$ and were exceeded only by Pin-tailed Parrotfinch Erythrura prasina $(417,228)$. These numbers do not include illegally exported Hill Mynahs.

Long-term collection of field data on Hill Mynah fledgling success from 1991 to 1998 in eight provinces of Thailand showed that only $12 \%$ of eggs hatched survived to independence while $61 \%$ of eggs hatched were lost to human theft (Archawaranon 2003). In contrast, in 1999 when nests were experimentally guarded 24 hours a day to prevent human interference, fledgling success increased to $75 \%$ of eggs hatched. 
A solution to this problem may lie in a successful captive breeding programme. Other approaches to bird conservation such as habitat restoration or dissemination of knowledge of the conservation importance of the species are likely to fail, especially in a developing country where people make their living by poaching. Captive breeding of threatened species in captivity and subsequent reintroduction has been successful for species such as the Puerto Rican Amazon Parrot Amazona vittata and the Venezuelan Yellow-shouldered Amazon Parrot Amazona barbadensis (Rice 2004). It can also play a significant role in providing a genetic reservoir for an endangered species.

I report here the details of successful captive breeding of Hill Mynah and include information on the development of the young and age-related differences in morphology. I also address the problems of reintroduction in bird conservation.

\section{Methods}

\section{Captive breeding site}

Captive breeding has been conducted since 1995 at the Zoological Research Station, Ramkhamhaeng University, Bangna Campus in Bangkok, central Thailand $\left(13^{\circ} 4 \mathrm{O}^{\prime} \mathrm{N}\right.$, $100^{\circ} 30^{\prime} \mathrm{E}$, approx. sea level). Normally, there are three seasons in a year: summer (February to April), rainy season (May to October) and winter (November to January). The average annual temperature is $27.9^{\circ} \mathrm{C}$, average rainfall is $1,244 \mathrm{~mm}$ and average relative humidity is $74 \%$. The $6,400 \mathrm{~m}^{2}$ area includes a variety of trees that provide fruits for birds: fig Ficus spp., black plum Eugenia spp., Indian plum Flacourtia spp., papaya Carica papaya and banana Musa spp.

Large aviaries $(4 \times 5 \times 3 \mathrm{~m}$ in dimension) were built to keep flocks of four to eight birds together in order to let them pair. The aviaries had double doors to prevent birds escaping when keepers entered to feed them or to clean the aviaries. In each aviary, food, drinking and bathing water, roosting places, and small houses with cavities were provided ad libitum. Trees with edible fruit were also planted inside the aviaries.

When two birds had paired, as indicated by continual and close association, they were transferred to smaller aviaries $(3 \times 4 \times 3 \mathrm{~m})$ which had a breeding cage $(1 \times 2 \times$ $2 \mathrm{~m}$ ) inside. This breeding cage was supported by four poles $1 \mathrm{~m}$ in height and covered with $I \times I \mathrm{~cm}$ wire mesh on all six sides to prevent rats from eating the eggs or young nestlings. The legs of this breeding cage stood in a shallow basin of water to prevent ants from disturbing the food or birds on the nest. Nest materials, both sticks and leaves, were provided.

Two kinds of cavities were tried in order to determine whether the type of cavity affected nesting and breeding activity: one type was made from part of a coconut trunk $30 \mathrm{~cm}$ in diameter, $45 \mathrm{~cm}$ in height and with a cavity depth of $30 \mathrm{~cm}$; the other was a nest-box constructed from plywood in a rectangular shape $30 \times 30 \times 50 \mathrm{~cm}$ in size with a cavity depth of $40 \mathrm{~cm}$. The plywood nest-box was used as a potential substitute in case coconut trunks were difficult to obtain. Each breeding cage was provided with one of these types of cavities.

The daily diet consisted of pellet meals (19\% protein, $8 \%$ fat, $5 \%$ fibre, $1.2 \%$ calcium, 5\% ash and 10\% moisture), ground boiled eggs, mealworms, ground shells, fresh fruits such as papaya, banana, Indian plum, black plum, figs, watermelon Citrulus lanatus, tomato Lycopersicum sp. and pepper Capsicum spp. 


\section{Breeding birds}

Both subspecies of Hill Mynah found in Thailand were used for breeding: G. $r$. intermedia, the northern bird, and G. r. religiosa, the southern bird (Lekagul and Round 1991, Archawaranon 2002). The birds, originally wild-caught, were collected from people who had them as cage pets. These people were cooperative and willing to donate them for this captive breeding programme after receiving an explanation of the value of wildlife conservation. All birds were of known age as I only chose ones that people had obtained as first-year birds. All birds had been pets for a known period of time and all had been kept solitarily and had never bred.

The captive breeding programme consisted of two generations. In the first generation, there were three age groups: 3-, 2- and 1-year-old birds which fledged in 1994, 1995 and 1996, respectively. Four to eight birds of the same subspecies were chosen at random for each of six aviaries, starting in December 1996. Birds were allowed to pair freely. Observations of activities such as allo-preening, flying, hopping, perching, eating, drinking, bathing and distance between birds were recorded in order to identify pairing behaviour. The first pair, 3-year-old birds, was removed to a breeding cage in July 1997. The remaining birds in large aviaries were randomly and repeatedly switched to different aviaries until they finished choosing their mates. Eventually, there were eight breeding pairs: five pairs of the northern birds and three pairs of the southern birds.

Twelve captive-bred birds from the first generation (from different parents and hatched in 1997 and 1998) were kept for pairing in two aviaries, six birds per aviary, to let them choose their mates in December 2000 in order to produce the second generation. Pairing behaviour was observed as before. The first pair was removed to breeding cages in April 2001. Random switching of the other birds was carried out until there were four breeding pairs.

\section{Nesting}

After a pair was transferred to a breeding cage with nest materials, nesting behaviour such as collecting grass and sticks and movement in and out of the nest-cavities was observed twice a day (o7hoo-09hoo and 15hoo-17hoo), from a blind built next to the breeding compartment. In the first generation, cavities made from coconut trunks were provided to four breeding pairs and nest-boxes to the other four pairs. In the second generation, only coconut trunk cavities were provided to the four breeding pairs.

\section{Laying eggs and incubation}

The presence of people was accepted by the birds as they had been kept in cages since they were young. The nests were inspected daily to determine egg-laying dates and the incubation period. Egg sizes were also measured.

\section{Nestling and fledgling}

After hatching, nestlings were removed from the nests and hand-reared with water and moist pellet meal (a combination of meat and bone, soy bean, poultry, corn gluten, wheat bean, yellow corn, tuna oil, vitamin E, calcium carbonate and salt) every 
half an hour for 15 days and every 2 hours afterwards. Mealworms and small pieces of papaya and banana were offered after day 20. Hand-feeding continued until day 50. During the first 15 days, nestlings were warmed with 100 watt lamps. Body mass and wing length were recorded from an age of $1-2$ days until 180 days. The amount of food given was calculated in grams per day per bird to determine food intake from day 1 or 2 to day 30. The differences in food intake between the northern and the southern birds were compared using a Student's $t$-test.

Re-nesting

After nestlings were taken, the parents' behaviours continued to be observed twice a day in case of re-nesting. Nest materials were also supplied.

\section{Results}

Pairing

The most easily recognized sign of pairing behaviour occurred when birds preened each other whilst perching together. Sometimes one bird lifted its head and its mate immediately preened its neck, and vice versa. When one flew, the mate always followed.

\section{Nesting}

Breeders started preparing to nest by hopping in and out of the cavity provided and showing vigilance by looking around and emitting calls while they were perching at the entrance to the cavity. They also showed 'ownership behaviour' when the keeper came near their cage: regardless of what they were doing outside the cavity, one of them would immediately fly to perch at the cavity entrance and make repeated loud calls. Both sexes made the nest but one member of the pair always spent longer than the other in the cavity during the nest-building period. This bird was subsequently determined to be the male based on sex chromosomes (Delhanty 1989, Archawaranon 2004). Nest-building activity continued for 7-8 days. The birds showed the same nesting behaviour and a prompt onset of nest-building in both the coconut trunk and the nest-box.

\section{Egg-laying}

Typically, the eggs were bright turquoise blue with scattered brown marks. Egg sizes of the captive-bred northern birds $(24.7 \pm 0.8 \times 34.8 \pm 1.1 \mathrm{~mm}, n=38)$ were obviously smaller than those of the captive-bred southern ones $(26.3 \pm 0.8 \times 37.1 \pm 1.4 \mathrm{~mm}$, $n=27$ ). 'Captive' eggs were not different in size to 'natural' ones (northern race: $24.4 \pm 0.8 \times 34.1 \pm 1.5 \mathrm{~mm}, n=164$; southern race: $26.9 \pm 0.9 \times 36.8 \pm 1.2 \mathrm{~mm}, n=$ 92) (Archawaranon 2003). Clutch sizes of birds bred in the coconut trunks were the same as those bred in the nest-boxes. Clutch size was $2.6 \pm 0.5(n=29)$.

\section{Incubation and hatching}

Incubation began when the female had completed her clutch. Both sexes incubated. During this period fresh leaves were brought into the cavity, perhaps to maintain 
suitable humidity or to reduce parasites (Clark and Mason 1988) or to support pairbonding (Feare 1984). At night only the female bird was found in the cavity with eggs.

Hatching began after 14-15 days (October 1997); thereafter, within each clutch, eggs hatched at 1 -day intervals. Chicks were hatched naked with eyes closed. The trace of a fleshy wattle was pale pink. Egg shells were removed from the nest by both sexes and usually found in the food tray or water container. The same number of nestlings, one or two per clutch, hatched in both coconut trunks and nest-boxes (1.9 \pm 0.4 , $n=29$ ) and the unhatched eggs were often destroyed by parents or left in the nest.

\section{Nestling and fledgling stages}

After learning that the young left in the nest survived only 2-3 days, I removed nestlings from the nests the day after hatching. The body masses at hatching of nestlings (northern race: $11.9 \pm 0.9 \mathrm{~g}, \mathrm{n}=32$; southern race: $14.3 \pm 0.9 \mathrm{~g}, n=22$ ) were not significantly different to those of wild young (northern race: $11.0 \pm 0.7 \mathrm{~g}, n=150$; southern race: $13.9 \pm 0.8 \mathrm{~g}, n=88$ ) (Archawaranon 2003). Southern nestlings were heavier in body mass and longer in wing length than their northern counterparts at all ages (Figure 1 ). The data on food intake indicated that southern nestlings at day 30 consumed significantly more food per day than did the northern ones $(t=-22.98$, $P<0.05)$.

On the third and fourth days, short feathers appeared from under the skin and black feathers covered the whole body within 25-27 days. On days 10-11, the eyes opened. The young birds started flapping their wings at day 20 and fledged at day 3540. The black colour on the tip of upper bill remained until 3 months old, the white gape between the upper and lower bills disappeared in 2 months and the pale pink wattles gradually turned to a yellow colour.
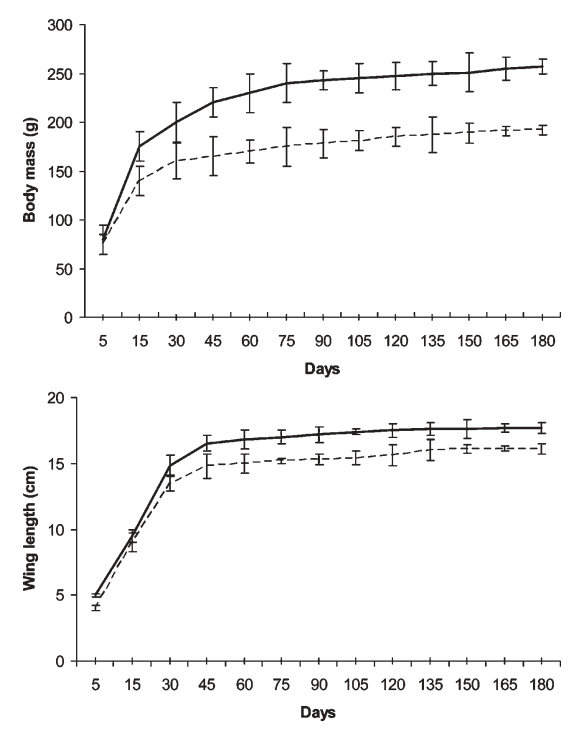

Figure 1. Comparisons of body mass and wing length between the captive-bred southern (unbroken line, $n=22$ ) and northern (dashed line, $n=30$ ) young Hill Mynahs. 
Re-nesting

After nestlings were taken from a nest, the parents started to build a nest again within 7-10 days. The second nest was finished in less time than the first: within 5-7 days as opposed to $7-8$ days for the first attempt.

\section{Number of fledglings}

There were a total of 52 fledglings in the first generation: 11 in 1997, 20 in 1998 and 21 in 1999. The second generation was hatched in June 2001 by four breeding pairs: 3-year-old captive-bred parents or the first generation which never bred before. The second generation produced a total of 28 fledglings: 13 in 2001 and 15 in 2002.

\section{Discussion}

Success in captive breeding

Success in breeding Hill Mynahs in captivity in this study was thought to be a result of the abundance of the essential requirements for reproduction and the lack of predation. Predators are often the most important factor in determining nesting success in the natural populations (Lack 1954, 1968, Nilsson 1984, Martin 1988). A study of Hill Mynahs' fledging success in Thailand from 1991 to 1998 showed that the proportion of nestling loss before fledging was $88 \%$ (Archawaranon 2003). Out of this number, losses due to natural predators and to human depredation were $27 \%$ and $61 \%$ respectively. In captivity less than $5 \%$ of nestlings were lost before fledging.

Food abundance was probably an important factor which stimulated reproduction in the captive Hill Mynahs. Food included protein from living mealworms, boiled eggs and pellet food, various vitamins from fresh fruits and vegetable, and calcium (from natural ground shells) which was important for egg shell formation. Food availability is known to affect reproductive activity in similar species. For example, European Starlings Sturnus vulgaris which received less food than their needs showed less courtship behaviour and did not start laying until they received their normal quantity of food (Meijer and Langer 1995). Perrins (1970) has suggested that the two main factors determining breeding time are the resource requirements for females to start egg-laying and for parents to feed the nestlings. The ad libitum presentation of food in this study would therefore have facilitated all elements of the breeding cycle.

Some studies have shown that nesting in boxes was more advantageous to cavitynesting birds than nesting in natural cavities as a result of lower predation rates in the former (e.g. Tree Swallows Tachycineta bicolor: Robertson and Rendell 1990; Pied Flycatchers Ficedula hypoleuca: Alatalo et al. 1990). Moreover, Purcell et al. (1997) reported that Western Bluebirds Sialia mexicana nesting in boxes initiated egg-laying earlier as well as having the higher nesting success due to lower predation rate. House Wrens Trogodytes aedon nesting in boxes laid larger clutches, hatched more eggs and fledged more young (Purcell et al. 1997). In my study there was no difference in the performance of the birds in coconut trunk cavities or plywood boxes. Obviously there were no predators in the captive situation to affect relative breeding success and the ad libitum rather than seasonally changing food may have prevented differences in the timing of egg-laying. 
Breeding throughout the year in this study has occurred as a result of the equable climate with no great change in day length, temperature and humidity in the captive breeding area (Archawaranon and Techatraisak 2002). The permanent availability of food, nest-cavities and nest materials may also have contributed to this.

\section{Bird conservation in Thailand}

At the tenth meeting of the conference of the parties to CITES (Convention on International Trade in Endangered Species of Wild Fauna and Flora) in Zimbabwe in June 1997, Hill Mynah was included in the CITES Appendix II for the first time. Although Hill Mynahs are legally protected in Thailand and the exportation of this species is prohibited, enforcing the ban is not practical - a similar situation to that in India - and large numbers of Hill Mynahs appear in different markets (Sane 1983, Menon 1994).

Since the report on the plight of Thailand's birdlife in 1973 (Martin 1973), there have also been reports on the trade in Hill Mynahs in India (Sane 1983, Menon 1993). The latter mentioned that, in 1979, 15,000-25,000 Hill Mynahs were collected for trade of which 3,000-5,000 were adult or semi-adults. By implication, 12,000-20,000 Hill Mynahs were collected as nestlings or fledglings. These figures indicate that Hill Mynahs are one of the favourite species for the pet market.

This demand for Hill Mynahs obviously encourages the poachers and endangers the wild populations. Moreover, more than $50 \%$ of birds in trade die before reaching their destination because of over-crowding in small cages which have inadequate food and water and are full of waste products (Archawaranon 2003).

Attempts to breed Hill Mynah in captivity have previously occurred in 1956 (Boosey 1957), 1979 (Ouse 1980) and 1992 (Scott 2004). These early attempts were successful in breeding but they may have made no contribution to conservation of the species since they were interested in breeding birds for the pet trade only. Bertram (1967) reported that the people in the Garo Hills district of Assam provided artificial nests for Hill Mynahs to breed. The artificial nests were bamboo-and-grass baskets attached to the branches at or near the tops of the tall trees. He mentioned that the 'Garos' could collect young with little difficulty from the accessible nests and prevented them from being taken by other poachers. He did not give the total number of young hatched from these artificial nests and the few thousand young Mynahs which were taken out of Assam each year for export also included birds from natural nests (Bertram 1967).

Captive breeding can play an important role in conserving species. It has the potential to reduce the threats to that species breeding in the wild and captive-bred individuals can serve as a demographic and genetic reservoir for the species. Captive breeding may in some cases be the only option for species extinct in their natural habitats (Primack 1993). Although captive breeding and possible subsequent reintroduction may be important for some species there are many problems (Cade and Seddon 1998). Adequate breeding stock has to be prepared and maintained and the captive-bred birds have to be trained, before their release, to avoid predators, find food, construct a nest, interact with conspecifics and find a mate. An appropriate site for the reintroduction must be established in the species' natural range and in areas with some degree of protection. The whole process is obviously very costly, time-consuming, requires long-term financial support and, most of all, long-term commitment. 
In Thailand where, because of financial constraints, there is a lack of time and money for an effective environmental education programme, successful reintroduction of the Hill Mynah seems impossible. Also, to replace losses of wild birds, a very large number of birds would have to be released and the poachers would presumably just collect the extra birds. A more realistic role for captive breeding may, therefore, be to supply the pet trade directly. If enough birds could be bred the price would be forced down and the pressure on collections from the wild would be automatically reduced. Another advantage of this approach is that the main input would be in feeding the young and these labour costs are quite cheap in a developing country. Moreover, captive-bred birds are tame, easily imprint on humans and are able to express more vocal mimicry of any sound (Archawaranon 2005). Birds reared specially for the trade are also more likely to survive transportation than birds taken from the wild (Archawaranon 2003).

Adopting this potential solution would require the cooperation of the wildlife agencies and appropriate legislation. The assumption by the government of Thailand that prohibiting trade will help this species to increase its numbers in the wild is not tenable and captive-breeding to supply the pet trade may be the only practical solution.

\section{Acknowledgements}

I thank R. H. Wiley and H. C. Mueller, The University of North Carolina at Chapel Hill, North Carolina, U.S.A. for their great inspiration in ornithological studies. This study was supported by the National Center for Genetics Engineering and Biotechnology, National Science and Technology Development Agency, Thailand and Ramkhamhaeng University.

\section{References}

Alatalo, R. V., Carlson, A. and Lundberg, A. (1990) Polygyny and breeding success of Pied Flycatchers nesting in natural cavities. Pp. 323-330 in J. Blondel, A. Gosler, J. D. Lebreton and R. McCleery, eds. Population biology in passerine birds. An integrated approach. Berlin: Springer.

Archawaranon, M. (2002) Zoogeography of various Hill Mynah phenotypes in Thailand. J. Biol. Sci. 2: 645-647.

Archawaranon, M. (2003) The impact of human interference on Hill Mynahs Gracula religiosa breeding in Thailand. Bird Conserv. Int. 13: 139-149.

Archawaranon, M. (2004) Rapid sexing of Hill Mynahs Gracula religiosa by sex chromosomes. Biotechnology 3: 160-164.

Archawaranon, M. (2005) Vocal imitation in Hill Mynas. Gracula religiosa: factors affecting competency. Int. J. Zool. Res. 1: 26-34.

Archawaranon, M. and Techatraisak, B. (2002) Subspecific size variation in the Hill Mynah Gracula religiosa in Thailand. J. Biol. Sci. 2: 785-788.

Bertram, B. (1967) Hill Myna Gracula religiosa Linnaeus breeding in artificial nests in Garo Hills, Assam. J. Bombay Nat. Hist. Soc. 64: 369-370.

Bertram, B. (1969) Hill Mynahs and the trade in them from India. Avicult. Mag. 75: 253-255.

Boosey, E. I. (1957) First breeding of the greater Hill Mynah (Eulabes religiosa) at the Keston foreign bird farm. Avicult. Mag. 63: 160-163.

Cade, T. J. and Seddon, P. J. (1998) Bird reintroduction: pre-release preparations release and post-release monitoring. Proc. 22 Int. Ornithol. Cong., Durban. Ostrich 69: 161. 
Clark, L. and Mason, J. R. (1988) Effect of biologically active plants used as nest material and the derived benefit to Starling nestlings. Oecologia (Berl.). 77: 174-180.

Delhanty, J. D. A. (1989) Rapid chromosomal sexing of birds by direct and short term culture techniques. Vet. Rec. 125: 92.

Feare, C. (1984) The Starling. Oxford: Oxford University Press.

Lack, D. (1954) The natural regulation of animal populations. London: Oxford University Press.

Lack, D. (1968) Ecological adaptation for breeding in birds. London: Methuen.

Lekagul, B. and Round, P. D. (1991) A guide to the birds of Thailand. Pp. 373-374. Bangkok: Saha Karn Bhaet.

Martin, R. M. (1973) The plight of Thailand's birdlife. Avicult. Mag. 79: 131-136.

Martin, T. E. (1988) Processes organizing open-nesting bird assemblages: competition or nest predation? Evol. Ecol. 2: 37-50.

Meijer, T. and Langer, V. (1995) Food availability and egg-laying of captive European Starlings. Condor 97: 718-728.

Menon, V. (1993) Hill Mynah trade. Newsl. Birdwatchers 33: 68-69.

Menon, V. (1994) The trade in Hill Mynas in India. TRAFFIC Bull. 14: 81-82.

Nilsson, S. G. (1984) Clutch size and breeding success of the Pied Flycatcher Ficedula hypoleuca in natural tree-holes. Ibis 126: 407-410.

Ouse, A. J. (1980) Observations of nesting of greater Hill Mynahs (Gracula religiosa) at Van Saun park zoo, Paramus, New Jersey, U.S.A. Avicult. Mag. 86: 5-9.

Perrins, C. M. (1970) The timing of birds' breeding season. Ibis 112: 242-255.

Primack, R. B. (1993) Essentials of conservation biology. Pp. 361-393. Sunderland, MA: Sinauer Associates.

Purcell, K. L., Verner, J. and Oring, L. W. (1997) A comparison of the breeding ecology of birds nesting in boxes and tree cavities. Auk 114: 646-656.

Rice, J. (2004) Reintroduction of parrots in the Greater Antilles and South America. http:// www.hort.agri.umn.edu/h5015/99papers/rice.htm, 13 March 2004.

Robertson, R. J. and Rendell, W. B. (1990) A comparison of the breeding ecology of a secondary cavity nesting bird, the Tree Swallow (Tachycineta bicolor) in nest-boxes and natural cavities. Can. J. Zool. 69: 1046-1052.

Sane, S. R. (1983) Some aspects of the wildlife/pet trade in India. Pp. 523-543. In J. C. Daniel and J. S. Serrao, eds. Conservation in developing countries: problems and prospects. Proceedings of the centenary seminar of the Bombay Natural History Society. Bombay: Oxford University Press.

Scott, L. (2004) Breeding the Java Hill Mynah. http://www.mynahbird.com/articles/breedingi/ 2/breeding1/2.html, 13 March 2004

\section{MANEE ARCHAWARANON}

Department of Biology, Faculty of Science, Ramkhamhaeng University, Bangkok 10240, Thailand. Tel: +661 4421695. Fax: +662 7296176. Email: maneemynah@yahoo.com

Received 5 July 2004; revision accepted 25 February 2005 